\title{
Homogeneous catalytic systems for selective oxidation of methane: state of the art
}

\author{
Sylwia Balcer \\ West Pomeranian University of Technology, Szczecin, Pulaskiego 10, 70-322 Szczecin, Poland \\ Corresponding author: e-mail: Sylwia.Balcer@zut.edu.pl
}

Homogeneous catalysts for methane oxidation are of a particular interest from scientific and economic points of view. The results show a great potential for activation and functionalization of $\mathrm{CH}$ bonds of unreactive methane. There are still gaps in the knowledge of how to rationally design catalysts for this process. In this paper state-ofthe-art. in methane oxidation homogenous catalysis is presented.

Keywords: alkane functionalization, methane, methanol, catalytic systems, homogeneous catalytic systems.

\section{INTRODUCTION}

Hydrocarbons, like methane, are some of the most available energy sources, unreactive and inert to most reagents, as we know it. These properties have limited their usefulness. Methane is the main constituent of natural gas, the simplest alkane and the most abundant member of the hydrocarbon family.

Because of the enormous reserves of natural gas in the world $\left(1.8 \times 10^{14} \mathrm{~m}^{3}\right)^{1}$, there is a strong economic incentive to develop a process that would convert methane into products such as syngas ${ }^{2,3}$, nanomaterials and hydrogen ${ }^{4-8}$ valuable chemicals or to more easily transported liquid fuel ${ }^{9}$.

Although methane can be applied as vehicle fuel, a good methane adsorbent is needed. Activated carbons are mainly investigated as a suitable material ${ }^{10-13}$.

Nevertheless methane is often difficult to use, because transportation of methane gas or even liquefied natural gas is expensive and dangerous.

Methane becomes a principal component of modern chemistry and, as such, plays a central role in our quality of life. As one of the most versatile raw material it is consumed by industry and household as an energy source. Methane can be a raw material for the chemical industry for the production of valuable chemicals, for example methanol. It has increasingly been viewed as a dependable and clean transportation fuel, powering urban mass transportation systems reliably and safely.

Catalytic oxidation of methane to produce oxygenates remains one of the challenges in catalysis field, and has attracted considerable interest since the $1907 \mathrm{~s}$ due to its scientific and industrial significance. However, the selective oxidation of methane to methanol is a challenging problem for catalytic science. Methane is the most stable and unreactive hydrocarbon, has the highest $\mathrm{C}-\mathrm{H}$ bond strength of all alkanes $\left(\Delta(\mathrm{C}-\mathrm{H})=438.8 \mathrm{~kJ} / \mathrm{mol}^{-1}\right)$, high ionization potential $(12.5 \mathrm{eV})$, low proton affinity $(4.4 \mathrm{eV})$ and low acidity $(\mathrm{pKa}=42)$ for which partial oxidation produces kinetically labile products ${ }^{14,54,61}$. These points necessitate the design of a catalytic system that not only activates this inert substrate, but is able to do so under intrinsically mild reaction conditions so as to avoid deeper oxidation. However, although low-temperature routes have been reported to proceed with increased selectivity, they do not yet do so at economical catalytic rates ${ }^{15}$ and its direct conversion to useful chemicals is very difficult ${ }^{16}$.
This present work is a review with emphasis on recent advances of catalysis in liquid phase.

\section{CATALYST DEVELOPMENT}

\section{Catalytic conversion of methane to methanol using solid catalysts}

Methane oxidation in gas - phase, under atmospheric pressure on solid catalysts, was presented in numerous publications ${ }^{17-34}$. Thus, a variety of compounds were used as contacts agents. The reaction was performed at $400-800^{\circ} \mathrm{C}$ and $0.1 \mathrm{MPa}$ pressure, by insufficiency of oxygen $\left(5-30 \%\right.$ vol. $\left.\mathrm{O}_{2}\right)$. Under these conditions formaldehyde was mainly obtained.

Particularly noteworthy was the publication of Yamada`s group ${ }^{17}$, which shows results using 43 different oxides of elements supported on silica. The process was performed at $500^{\circ} \mathrm{C}$. Contact time lasted $0.75 \mathrm{~s}$. The oxygen content of the mixture was varied from 5 to $30 \%$ Vol. V, Fe, Sc, W, Mo and Os oxides were found to be good catalysts in these conditions.

There are known publications in which attempts were made to create a mixture of several oxides as a catalyst system, based on the experimental results obtained by using each of compounds alone. Pioneering work was done by Otsuka ${ }^{18}$, who studied oxide- catalysts supported on silica. With the increase in electronegativity of an oxide compound, the conversion first is growing up and then decreasing, while the selectivity of conversion into formaldehyde with grows the increase of electronegativity. Then two catalysts were used, one with high, and the other with average values of electronegativity. The highest degree of conversion was achieved for magnesium and boron oxides (Table 1).

Table 1 presents catalyst systems, the use of which has resulted in higher conversion into formaldehyde. Unfortunately, despite years of research, the problem of obtaining a higher yield of formaldehyde than a few percent is still unresolved.

Parmaliana et al ${ }^{30}$ received formaldehyde at $650^{\circ} \mathrm{C}$ and $\mathrm{SiO}_{2}$ as catalysts with a yield of $17 \%$. The use of ZSM $-5^{34}, \mathrm{Fe}-\mathrm{ZSM}-5^{35,36}$ allowed to receive methanol with the yield of a few percent.

All research about oxidation of methane on solid catalysts by the high selectivity was characterized by low conversion and resulted low yield. The main issue regarding the yield of this reaction is the overoxidation 
Table 1. Overview of solid catalysts in partial oxidation of methane at atmospheric pressure

\begin{tabular}{|c|c|c|c|}
\hline Catalyst & Temperature $\left[{ }^{\circ} \mathrm{C}\right]$ & Conversion $\mathrm{CH}_{4}$ into $\mathrm{HCHO}[\% \mathrm{Mol}]$ & References \\
\hline $\mathrm{V}_{2} \mathrm{O}_{5} / \mathrm{SiO}_{2}$ & 650 & 4.72 & 19 \\
\hline $\mathrm{MoSn} / \mathrm{SiO}_{2}$ & 700 & 4.66 & 20 \\
\hline $\mathrm{Fe}_{2} \mathrm{O}_{3}\left(\mathrm{MoO}_{3}\right)_{2.25}$ & 700 & 4.00 & 21 \\
\hline $\mathrm{MoO}_{3} / \mathrm{SiO}_{2}$ & 650 & 1.70 & 22 \\
\hline FeNbBo & 770 & 1.36 & 23 \\
\hline $\mathrm{SiO}_{2}$ & 620 & 1.15 & 24 \\
\hline $\mathrm{FePO}_{4} / \mathrm{SiO}_{2}$ & 600 & 1.20 & 25 \\
\hline $\mathrm{Zr}-\mathrm{P}-\mathrm{O}$ & 777 & 0.64 & 26 \\
\hline $\mathrm{MgB}-\mathrm{O} / \mathrm{SiO}_{2}$ & 650 & 0.60 & 18 \\
\hline $\mathrm{MgO}$ & 750 & 0.42 & 27 \\
\hline $\mathrm{Cu}-\mathrm{Fe} / \mathrm{ZnO}$ & 750 & 0.25 & 19 \\
\hline $\mathrm{BMo}-\mathrm{O} / \mathrm{SiO}_{2}$ & 545 & 0.05 & 20 \\
\hline $\mathrm{T}, \mathrm{H}, \mathrm{M}$ form of $\mathrm{Nb}_{2} \mathrm{O}_{5}$ & 350 & $0.4-0.6$ & 28 \\
\hline
\end{tabular}

to $\mathrm{CO}$ or $\mathrm{CO}_{2}$. Under mild conditions the activation of methane was very difficult.

The above processes of methane oxidation take place at high temperatures $\left(350-800^{\circ} \mathrm{C}\right)$. The first stage is $\mathrm{C}-\mathrm{H}$ bond cleavage and the formation of the $\mathrm{CH}_{3}^{-}$ radical ${ }^{20-22,37,38}$. The construction of methane molecule and its properties limited the efficiency of oxidation for only few percent. Furthermore, dissociation energy of the $\mathrm{C}-\mathrm{H}$ bond in methane molecule is higher than the energy in methanol or formaldehyde molecule. Products are more reactive than their substrates.

In 1972 Shilov et al. showed that platinum ions can activate $\mathrm{C}-\mathrm{H}$ bond under mild conditions without radical reaction. This involves interaction of the metalorganic complex and sigma bond electron pair. The intermediate compound is the so - called "sigma complex". The mechanism of $\mathrm{C}-\mathrm{H}$ activation by molecular complexes for homogeneous processes has been extensively investigated; four mechanisms involving at least one metal center have been documented: oxidative addition (usually for late transition metal), $\sigma$-bond metathesis for their early counterparts, and, in a few cases, 1, 2-addition or electrophilic activation ${ }^{\mathbf{3 9}, 40}$.

Basset, Sun et al. presented an overview of heteropoly compounds in catalytic oxidation of light alkanes $\left(\mathrm{C}_{1}-\mathrm{C}_{4}\right)$, mechanism of the reaction and the impact of various factors ${ }^{71}$.

Methane oxidation in the aqueous systems or similar In 1972 Shilov`s group ${ }^{\mathbf{4 1}}$ were able to oxidize methane at $120^{\circ} \mathrm{C}$ and $3.7-4.3 \mathrm{MPa}$ methane pressure. The reaction was performed in the aquatic solution of $\mathrm{H}_{2} \mathrm{PtCl}_{6}$ and $\mathrm{Na}_{2} \mathrm{PtCl}_{4}$. The products in liquid phase were methanol and halogenoalkanes - mainly methyl chloride.

The oxidation of the simplest alkane with oxygen and carbon monoxide to acids in an aquatic solvent of 0.1 $\mathrm{N} \mathrm{HCl}$, at $70-200^{\circ} \mathrm{C}$ was developed by Sen and Lin. As a catalytic system the authors recommended metallic palladium ${ }^{42}$ or $\mathrm{RhCl}_{3}{ }^{43,44}$. Using metallic palladium at $70-100^{\circ} \mathrm{C}$ on an active carbon support they obtained formic acid and methanol. The use of $\mathrm{RuCl}_{3}$ as the catalytic system allowed to convert methane at $100^{\circ} \mathrm{C}$ and $5.52 \mathrm{MPa}$ partial methane pressure. The main product was acetic acid; with formaldehyde and methanol.

$$
\begin{array}{ll}
L_{m} M^{n}+R-H \rightarrow L_{m} M^{n+2} & \text { Oxidative addition } \\
L_{m} M^{n}-R^{\prime}+R-H \rightarrow L_{m} M^{n}-R+R^{\prime}-H & \\
& \\
L_{m} M^{n}=X+R-H \rightarrow L_{m} M^{n}-X & \\
L_{m} M^{n}-X+R-H \rightarrow L_{m} M^{n}-R+H X & \\
\end{array}
$$


Park et al. ${ }^{45,46}$ oxidized methane in an aquatic solution of trifluoroacetic using metallic palladium on an active carbon support and $\mathrm{Cu}\left(\mathrm{CH}_{3} \mathrm{COO}\right)_{2}$ catalysts. The main product was trifluoromethyl acetate and formic acid was a by-product.

\section{Methane oxidation in other organic solvent systems}

Ellis et al. ${ }^{47,48}$ developed an oxidation method of paraffins with molecular oxygen in the presence of porphyrins that contain cyanide groups and halogen atoms. Hydrocarbons, including methane, were oxidized by oxygen from air at $70-180^{\circ} \mathrm{C}$ and $0.2-5.2 \mathrm{MPa}$ methane pressure. The reaction was performed in liquid phase, in organic solvents such as: $\mathrm{C}_{6} \mathrm{H}_{6}, \mathrm{CH}_{3} \mathrm{COOH}$, acetonitrile, methylacetate, methyl acetate and others, which are inert in these reaction conditions. The catalysts used are transition metals $\mathrm{Fe}, \mathrm{Cr}, \mathrm{Mn}, \mathrm{Ru}, \mathrm{Cu}, \mathrm{Co}$. The corresponding alcohols were prepared in the reaction.

Süss-Fink et al. ${ }^{\mathbf{4 9}, \mathbf{5 0}}$ investigated different types of similar catalytic systems. In the first case methane was oxidized by air in an acetonitrile solution, in the presence of $\left[\mathrm{NBu}_{4}\right] \mathrm{VO}_{3}-$ pyrazine -2 - carboxylic acid used as the catalyst and $35 \% \mathrm{H}_{2} \mathrm{O}_{2}$ used as the promoter. The main product under $35^{\circ} \mathrm{C}$ was methyl hydroperoxide, easily reduced to methanol. In higher temperature prevailed formaldehyde and formic acid. In the second case sodium orthovanadate was used as the catalyst and 35\% $\mathrm{H}_{2} \mathrm{O}_{2}$ in water solution as the promoter were used - the only product was methyl hydrogen peroxide.

Lee et al. $^{51}$ and Peng ${ }^{52}$ oxidized methane with oxygen in molten salts. The Lee group used sodium and potassium nitrate in $526-600^{\circ} \mathrm{C}$ at $0.1 \mathrm{MPa}$ pressure. Mainly methanol and carbon oxides were obtained; the reaction yield was $0.47 \%$ with a degree of methane conversion at $8.2 \%$. Peng et al. used a mixture of silver and sodium nitrate with other catalysts: $\mathrm{Cu}\left(\mathrm{CF}_{3} \mathrm{CO}_{2}\right)_{2}, \mathrm{Co}\left(\mathrm{CF}_{3} \mathrm{CO}_{2}\right)_{2}$, $\mathrm{Ce}\left(\mathrm{SO}_{4}\right)_{2}, \mathrm{MnSO}_{4}$ and $\mathrm{CuSO}_{4}$. The reaction proceeded at $160^{\circ} \mathrm{C}$ under $3.5 \mathrm{MPa}$ of methane and $0.5 \mathrm{MPa}$ of oxygen pressure. The post - reaction gases contained methyl trifluoroacetate and propanone.

Sherman patented a method of methane oxidation in water, by a free radical mechanism ${ }^{\mathbf{5 3}}$. In a reactor of a special design, $\mathrm{OH}$ radicals were produced, which generated the production of $\mathrm{CH}_{3}{ }^{*}$.

Staufer developed a method of methane oxidation with oxygen at $200-375^{\circ} \mathrm{C}$, using organic chlorine compounds ${ }^{54}$. The process consisted of two phases and the only product was methanol. Copper (I) chloride was the reaction catalyst.

Seki et al..$^{\mathbf{5 5}, \mathbf{5 6}}$ investigated methane oxidation in the presence of heteropoly acids. The heteropoly acids and $\mathrm{H}_{2} \mathrm{O}_{2}$ were dissolved in the anhydride of trifluoroacetic acid, methyl cyanide and water. The reaction was carried out at $50-80^{\circ} \mathrm{C}$ and $5 \mathrm{MPa}$ methane pressure. The reaction products were: $\mathrm{CH}_{3} \mathrm{OH}, \mathrm{HCOOH}, \mathrm{HCOOCH}_{3}$, $\mathrm{CF}_{3} \mathrm{COOCH}_{3}, \mathrm{C}_{2} \mathrm{H}_{6}, \mathrm{CO}_{2}$.

\section{Methane oxidation in the strong acids}

Periana et al. ${ }^{57}$ developed a method of hydrocarbon conversion into alcohols, thiols, esters and halogenoalkanes. Instead of using water, an acid was used. The main product was an ester, which was stable in this environment of reaction. The desired product was pre- pared by reaction with a nucleophilic compound. The overall process, using methane as an example, may be outlined in the following fashion:

$$
\begin{aligned}
& \mathrm{CH} 4+\text { oxidant }+ \text { acid } \stackrel{\text { Cat. }}{\longrightarrow} \text { methyl oxyester of acid }+ \text { reduced oxidant } \\
& \text { methyl oxyester of acid }+ \text { nucleophile } \rightarrow \text { methyl intermediate }+ \text { acid } \\
& \text { methyl intermediate } \stackrel{\text { Cat.2 }}{\longrightarrow} \text { hydrocarbon }+ \text { nucleophile } \\
& \text { Net reaction: } \mathrm{CH} 4+\text { oxidant } \rightarrow \text { hydrocarbon }+ \text { reduced oxidant }
\end{aligned}
$$

The first step involves contacting methane with an acid and an oxidizing agent in the presence of a catalyst. The acid may be an organic or inorganic acid such as $\mathrm{HNO}_{3}, \mathrm{H}_{2} \mathrm{SO}_{4}, \mathrm{CF}_{3} \mathrm{CO}_{2} \mathrm{H}, \mathrm{CF}_{3} \mathrm{SO}_{3} \mathrm{H}, \mathrm{H}_{3} \mathrm{PO}_{4}$ or the like. The preferred acids are strong inorganic acids $(\mathrm{pKa}<$ 2.0) and especially preferred are $\mathrm{H}_{2} \mathrm{SO}_{4}$ and $\mathrm{CF}_{3} \mathrm{SO}_{3} \mathrm{H}$. The acids should be oxidation resistant: they should not be oxidized by the catalyst metal in the noted reaction medium. In addition to acting as a reactant, the acid desirably is used in excess and thereby acts as a reaction medium as well ${ }^{\mathbf{4 1}}$. The preferred oxidizing agents are $\mathrm{O}_{2}$, $\mathrm{H}_{2} \mathrm{SO}_{4}, \mathrm{SO}_{3}, \mathrm{HNO}_{3}, \mathrm{H}_{2} \mathrm{SeO}_{4}$.

The catalysts used in Eq. 1 are transition metals, i.e., $\mathrm{Cu}, \mathrm{Zn}, \mathrm{Pd}, \mathrm{Ad}, \mathrm{Cd}, \mathrm{In}, \mathrm{Sn}, \mathrm{Sb}, \mathrm{Te}, \mathrm{Pt}, \mathrm{Au}, \mathrm{Hg}, \mathrm{Tl}, \mathrm{Pb}$, $\mathrm{Bi}, \mathrm{Ga}, \mathrm{Ge}, \mathrm{As}, \mathrm{Po}, \mathrm{Rh}, \mathrm{Ir}$, Os and $\mathrm{Ru}^{58-62}$. The authors recommended the following conditions: temperature at $50-30^{\circ} \mathrm{C}$ and $0.4-3.2 \mathrm{MPa}$ of methane pressure.

Especially sulfuric acid at a high concentration was preferred. This substrate was not only a solvent or an oxidizing agent - basically water could remove itself from the reaction.

The second step is the conversion of methyl ester to methanol and regeneration of acid which was used in the first step. In each case the major product in liquid phase was methyl intermediate which e.g. could be hydrolyzed into methanol.

\section{Mercury compounds as catalysts}

Periana et al. ${ }^{63}$ suggested a homogeneous catalytic system using $\mathrm{Hg}$ (II) salt as the catalyst in fuming sulfuric acid. The reaction took place at $180^{\circ} \mathrm{C}$ and 3.45 $\mathrm{MPa}$ methane pressure. Methane was oxidized to methyl bisulfate. $\mathrm{CH}_{3} \mathrm{OSO}_{3} \mathrm{H}$ was further hydrolyzed to produce methanol.

$$
\mathrm{CH}_{4} \stackrel{\mathrm{Hg}(\mathrm{II}), \mathrm{H}_{2} \mathrm{SO}_{4}, 180^{\circ} \mathrm{C}}{\longrightarrow} \mathrm{CH}_{3} \mathrm{OSO}_{3} \mathrm{H}
$$

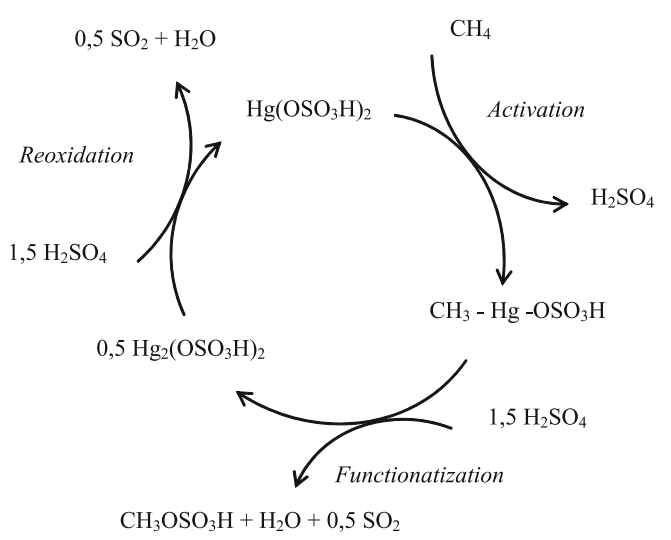

Scheme 2. The possible mechanisms for the activation of methane $\mathrm{C}-\mathrm{H}$ bond on the $\mathrm{Hg}^{2+}-\mathrm{H}_{2} \mathrm{SO}_{4}$ catalyst $^{63}$ 
Gang et al. ${ }^{64}$ applied a similar catalytic system as Periana's group but fuming sulfuric acid was more concentrated (65 wt $\left.\% \mathrm{SO}_{3}\right)$. The methane oxidation was studied at a temperature range of $150-200^{\circ} \mathrm{C}$ and of 4-10 MPa methane pressure.

Sen et al. ${ }^{\mathbf{6 5}, \mathbf{6 6}}$ investigated the catalytic properties of $\mathrm{HgSO}_{4}$ and other sulfates such as $\mathrm{Ce}\left(\mathrm{SO}_{4}\right)_{2}, \mathrm{PdSO}_{4}$ in sulfuric acid. The reaction took place at $90^{\circ} \mathrm{C}$ and $160^{\circ} \mathrm{C}$ and 6.9 $\mathrm{MPa}$ methane pressure. In higher temperature methane was oxidized to methyl bisulfate, in lower temperature to methanesulfonic acid.

Bell et al. ${ }^{67}$ investigated direct sulfonation of methane with $\mathrm{SO}_{3}$ to methanesulfonic acid and methylbisulfate using $\mathrm{Hg}(\mathrm{I}), \mathrm{Hg}(\mathrm{II})$, and $\mathrm{Rh}(\mathrm{III})$-salts as catalysts. The results of this investigation showed that after $5 \mathrm{~h}$ at $148^{\circ} \mathrm{C}$ and $2.5 \mathrm{MPa}$ of methane pressure using fuming sulfuric acid as the solvent, the corresponding MSA selectivity was $87 \%$. The authors proposed a mechanism for the formation of MSA and $\mathrm{CH}_{3} \mathrm{OSO}_{3} \mathrm{H}$ in the light of the experimental results.

$\mathrm{Fu}$ and co-workers summarized the possible mechanisms for the activation of methane $\mathrm{C}-\mathrm{H}$ bond, which were calculated on the basis of model catalysts: $\mathrm{V}_{3} \mathrm{O}_{6} \mathrm{Cl}_{3}$, $\mathrm{Cr}_{3} \mathrm{O}_{9}, \mathrm{Mo}_{3} \mathrm{O}_{9}$, and $\mathrm{W}_{3} \mathrm{O}_{9}{ }^{40,68}$.

Other studies into the activation of dioxygen at transition metals and main group element surfaces ${ }^{\mathbf{6 9}}$ provided evidence for transient species and intermediates $\mathrm{O}^{-}$and $\mathrm{O}^{2-}$, and of their reactions with $\mathrm{C}-\mathrm{H}$ bonds. The oxydehydrogenation reactions, efficient at low temperatures, are inhibited by thermally induced ordering of oxygen states and the accompanying surface reconstruction ${ }^{\mathbf{7 0}}$.

\section{Palladium compounds as catalysts}

Kao et al. ${ }^{72}$ suggested a homogenous catalytic system using a salt of $\mathrm{Pd}$ (II) as a catalyst and $\mathrm{H}_{2} \mathrm{O}_{2}$ as an initiator in $\mathrm{CF}_{3} \mathrm{COOH}$ medium. Trifluoroacetic acid was first oxidized to trifluoroperacetic acid. Then, a reaction between methane and trifluoroperacetic acid was catalyzed by $\mathrm{Pd}$ (II) and methyl ester of trifluoroperacetic acid was obtained. The ester can be hydrolyzed to produce methanol. The reaction was performed at a temperature equal to $80^{\circ} \mathrm{C}$ and $5.5 \mathrm{MPa}$ of methane pressure.

Taylor and co-workers ${ }^{73}$ reported that a reaction occurred between methane at $5.52 \mathrm{MPa}$ and palladium (II) acetate in trifluoroacetic acid at $80^{\circ} \mathrm{C}$. The product - methyl trifluoroacetate, was than hydrolyzed to produce methanol and trifluoroacetic acid.

The use of metallic palladium as the catalyst was very difficult because it is not soluble in sulfuric acid even after heating. Michalkiewicz et al. ${ }^{59}$ studied the oxidation of methane to organic oxygenates over metallic palladium dissolved in oleum. The reaction was carried out under the following conditions: temperature $160^{\circ} \mathrm{C}$, pressure of methane $3.5 \mathrm{MPa}$, time $2 \mathrm{~h}$, content of sulfur trioxide in fuming sulfuric acid $30 \%$ and the catalytic system $\operatorname{Pd}(0)$ in the form of palladium powder dissolved in fuming sulfuric acid.

The catalytic process relies on the formation of an unstable metal-organic complex $\mathrm{Pd}^{2+}-\mathrm{CH}_{3}$ which reacts with sulfuric acid. The carbon atom undergoes oxidation to methyl bisulfate while palladium is reduced to $\operatorname{Pd}(0)$. The methane conversion could not proceed in the case of metallic $\mathrm{Pd}$ without free $\mathrm{SO}_{3}$ because the first stage of the catalytic process would not take place.

As a result, the catalyst life as well as the reaction selectivity was higher than that when using palladium (II) sulfate.

Michalkiewicz ${ }^{74}$ found, that the rate of ester formation depends on the partial pressure of methane, the concentration of free sulphur trioxide in sulphuric acid, and concentration of methyl ester. The palladium - oleum catalytic system was used (concentration of $\mathrm{Pd}$ powder in oleum, $1.55 \mathrm{wt} \%$ ), which generate an ester of methanol by the low temperature process and $4.5 \mathrm{MPa}$ of methane pressure. The experiments were carried out in two series: the first one in the constant reaction time of 2 hours and temperature range at $90-160^{\circ} \mathrm{C}$; the second over the period from $1-20$ hours at $160^{\circ} \mathrm{C}$.

The kinetics of the partial methane oxidation process ${ }^{75}$ in the $\mathrm{Pd} \mid$ oleum was investigated too. The methane esterification process was carried out at $180^{\circ} \mathrm{C}$ in an autoclave containing oleum, using palladium as a catalyst. Then methyl esters were converted into methanol. The influence of the pressure on methane conversion and productyields were studied. The methane pressure was either varied from 1.5 to $5 \mathrm{MPa}$ or was kept constant at 3.0 MPa.

In the latter case, the partial pressure of methane was changed by the addition of nitrogen as the inert gas into the autoclave. At the constant methane partial pressure, the total pressure changes have no influence on the process. Only the methane partial pressure influences the process.

On the basis of the experiments it may be concluded that:

a) the process of methane oxidation in the condensed phase can be conducted at the atmospheric pressure,

b) at a constant methane partial pressure, the total pressure changes have no influence on the process,

c) increasing methane partial pressure allows to extend the amount of methanol and carbon dioxide,

d) elevating methane partial pressure in the autoclave does not influence the methanol yield but increases the carbon dioxide yield,

e) the rate of the reaction of forming ester is proportional to methane partial pressure.

Other studies ${ }^{76}$ focused on the impact of catalyst type on the esterification process. Michalkiewicz found that using the powdered palladium catalyst, methyl bisulphate and formaldehyde were obtained, which were subsequently oxidized to carbon dioxide. When platinum (IV) chloride was used as the catalyst of methane oxidation, after 2 hours methyl bisulphate was the only product. It was found too, that the addition of either carbon dioxide or ester into the reaction mixture did not slow down the reactions.

An attempt was made ${ }^{77}$ to apply membrane distillation as the second step of conversion of methane to methanol. In this study the possibility of application of a LPMD (low pressure membrane distillation) for the separation of ester - oleum mixture was investigated. The efficiency of ester separation was close to $100 \%$.

Michalkiewicz et al. investigated the hydrolysis process of methyl ester. The disadvantage of the conversion of methane to methanol in oleum via methyl bisulphate is 
production of sulphuric acid and a very large amount of water consumption. The authors propose the extraction of the ester before hydrolysis in order to solve these problems.

Membrane distillation for the separation of ester oleum mixture was applied.

\section{Platinum compounds as catalysts}

Platinum complex catalysts in fuming sulfuric acid (20 wt $\%$ ) were reported by Periana et al. ${ }^{78}$ for direct, oxidative conversion of methane to ester. The reaction was performed at $180^{\circ} \mathrm{C}$ and $3.45 \mathrm{MPa}$ methane pressure. The catalysts were platinum complexes derived from the bidiazine ligand family that were stable, active, and selective for the oxidation of a carbon- hydrogen bond of methane to produce methyl esters.

Michalkiewicz et al. ${ }^{\mathbf{7 9}, 80}$ studied the selective catalytic oxidation of methane in $25 \mathrm{wt} \%$ oleum to methyl bisulfate at ambient pressure and in the presence of $\mathrm{PtCl}_{4}$ (Eq. 6). The study was directed toward methane esterification at ambient pressure. The reaction was performed at $130-220^{\circ} \mathrm{C}$. It was shown that it is possible to functionalize methane at $0.1 \mathrm{MPa}$ using a large surface area that was shown to facilitate liquid - gas contact.

$$
\mathrm{CH}_{4} \stackrel{\mathrm{PtCl} 4}{\longrightarrow} \mathrm{CH}_{3} \mathrm{OSO}_{3} \mathrm{H}
$$

Eq. 6

\section{Iodine compounds as catalysts}

Gang et al. ${ }^{\mathbf{1}}$ applied a new series of iodine compounds as catalysts for the selective oxidation of methane to methyl sulfates in oleum (65 wt $\%)$. A mathematical model for the relationship between the initial reaction rate and the iodine concentration and methane pressure was given. The reaction was performed in the range $170-190^{\circ} \mathrm{C}$ and $4 \mathrm{MPa}$ methane pressure.

Periana et al..$^{\mathbf{2}}$ applied a similar catalytic system as Gang`s group, but they used iodine dissolved in sulfuric acid (0.5-3 wt\% $\left.\mathrm{SO}_{3}\right)$. Several experiments were performed at $195^{\circ} \mathrm{C}$ and $3.4 \mathrm{MPa}$ methane pressure.

Zarella and Bell ${ }^{83}$ used Pt(II) cations as the catalyst and sulfuric acid as the solvent. The reactions were carried out at $180^{\circ} \mathrm{C}$ in a sealed batch reactor containing either fuming or concentrated (96 wt \%) sulfuric acid and $\mathrm{PtCl}_{2}$ in the liquid-phase, and with $2.75 \mathrm{MPa}$ of $\mathrm{CH}_{4}$ and $\mathrm{CO}$ pressure. Pt (II) in concentrated sulfuric acid catalyzed the oxidative carbonylation of methane to acetic acid but excessively high CO partial pressures had to be avoided, since they contributed to the reduction of active $\mathrm{Pt}(\mathrm{II})$ to inactive $\operatorname{Pt}(0)$.

Michalkiewicz et al. ${ }^{\mathbf{8 4}, 85}$ performed methane oxidation to methyl bisulfate in the presence of iodine as a catalyst at ambient and higher pressure. In order to obtain high methyl bisulfate yield at $0.1 \mathrm{MPa}$ high sulfur trioxide concentration and low methane flow is recommended. The optimum of temperature is equal to $130^{\circ} \mathrm{C}$. It was showed that at methane pressure of $1-5 \mathrm{MPa}$ the reaction is of the first order with methane pressure and sulfur trioxide concentration. In the temperature range $80-180^{\circ} \mathrm{C}$, sulfur trioxide concentration $0-5.95$ moldm $^{-3}$ the reaction rate was well defined by an empirical equation.

\section{Other compounds as catalysts}

Vargaftik et al. $^{\mathbf{8 6}}$ carried out research by using TFA and trifluoroacetate salts of Co (III), Mn (II), Fe(III), $\mathrm{Cu}$ (II), $\mathrm{Pb}$ (IV). At $100-200^{\circ} \mathrm{C}$ and $1-4 \mathrm{MPa}$ of methane pressure only the methyl ester of trifluoroperacetic acid were received. The best results were obtained for Co (II) salt (yield at $90 \%$ calculated as metal).

Otsuka et al. ${ }^{\mathbf{8 7}, \mathbf{8 8}}$ proposed a catalytic system $\mathrm{EuCL}_{3}-$ $\mathrm{Zn}-\mathrm{CF}_{3} \mathrm{CO}_{2} \mathrm{H}$ which was used to oxidize methane with oxygen into methyl trifluoroacetate. Carbon dioxide was a by-product. Partial methane pressure was at $1.6 \mathrm{MPa}$ and oxygen pressure at $0.4 \mathrm{MPa}$. After one hour the degree of methane conversion to $0.9 \%$ was obtained. The addition of $\mathrm{TiO}_{2}$ increased methane conversion by $1.75 \%$.

Sen et al. ${ }^{65}$ used $\mathrm{K}_{2} \mathrm{~S}_{2} \mathrm{O}_{8}$ as the catalyst in fuming sulfuric acid. At $160^{\circ} \mathrm{C}$ under $6.9 \mathrm{MPa}$ of methane pressure methyl bisulfate and at $90^{\circ} \mathrm{C}$ only the methanesulfonic acid, were obtained. A degree of methane conversion for each of the products reached a few percent.

Bell and Mukhopadhyay ${ }^{\mathbf{8 9}, 90}$ carried out direct liquidphase sulfonation of methane to methanesulfonic acid by $\mathrm{SO}_{3}$ in the presence of cerium (IV) sulfate or metal peroxide. Methanesulfonic acid was obtained in fuming sulfuric acid, with a small amount of catalyst, which was added to the liquid phase. The selectivity achieved $99.9 \%$ for MSA product, using $\mathrm{Ce}\left(\mathrm{SO}_{4}\right)_{2}$ as the catalyst. Calcium peroxide proved the best initiator for the reaction conditions used. The peroxides of strontium and lead were only minimally more effective in promoting the sulfonation of methane.

The use of potassium peroxydiphosphate $\left(\mathrm{K}_{4} \mathrm{P}_{2} \mathrm{O}_{8}\right)$ as the initiator in a high-yield, direct sulfonation ${ }^{91}$ of methane with $\mathrm{SO}_{3}$ in sulfuric acid led to obtaining MSA acid. The effects of initiator concentration, temperature, $\mathrm{CH}_{4}$ pressure, the initial concentration of $\mathrm{SO}_{3}$, and solvent acidity were investigated.

Periana et al. ${ }^{\mathbf{9 2}}$ proposed selective oxidation of methane to methanol catalyzed, with $\mathrm{C}-\mathrm{H}$ activation by cationic gold. In strong acid solvents such as triflic or sulfuric acid, $\mathrm{Au}(\mathrm{III})$ cations using $\mathrm{Se}(\mathrm{VI})$ ions as the stoichiometric oxidant (generated by dissolution ${ }^{93}$ of $\mathrm{Au}_{2} \mathrm{O}_{3}$ ), react with methane at $180^{\circ} \mathrm{C}$ to selectively generate methanol, as a mixture of the ester and methanol, in high yield. The reaction does not appear to proceed through free radicals and DFT calculations indicate that $\mathrm{Au}(\mathrm{I})$ or $\mathrm{Au}(\mathrm{III})$ species are both viable catalysts that operate by mechanisms involving overall electrophilic $\mathrm{C}-\mathrm{H}$ activation and oxidative functionalization.

Another publication by Periana`s group ${ }^{\mathbf{4}}$ showed selective oxidization of mixtures of methane, ethane, and propane to alcohol esters. They reported that the electrophilic main- group cations of thallium (III) and lead (IV) oxidize methane and other alkanes to corresponding esters in a trifluoroacetic acid solvent. Esters were obtained with greater than $95 \%$ selectivity within 3 hours at $180^{\circ} \mathrm{C}$. This experiment confirms a mechanism involving electrophilic carbon-hydrogen bond activation to generate metal alkyl intermediates.

In chemical literature we can find increasingly more information about the use of bromide compounds for selective oxidation of methane to methanesulfonic ester.

Wang group ${ }^{\mathbf{9 5}}$ synthesized acetyl bromide and acetic acid from methane. They developed $\mathrm{Ru} / \mathrm{SiO}_{2}$ catalyst 
for the OBM reaction and a $\mathrm{RhCl}_{3}-\mathrm{PPh}_{3}$ system for the carbonylation of $\mathrm{CH}_{3} \mathrm{Br}$. Acetyl bromide could be hydrolysed readily to anhydrous acetic acid or alcoholised to produce esters.

Fengbo et al. ${ }^{96}$ presented a novel bromine-mediated process over $\mathrm{HgO}$ supported nanophases for selective methane partial oxidation at a relatively low reaction temperature. The studies included synthesis of the catalysts, activity tests, the investigations about the role of bromine in the catalytic cycle and characterizations of the catalysts. The study found that the chemical composite changes of active species, which provide some direct information about the mediator role of bromine in the catalytic cycle and its influence on the mechanism for conversion of methane to $\mathrm{C} 1$ oxygenates.

Chan and co-workers ${ }^{97}$ developed an efficient catalyst for controlled oxidation of small alkanes under ambient conditions. The tricopper complex [CuICuICuI(7N-Etppz)]1+, where 7-N-Etppz denotes the ligand 3,3'-(1,4-diazepane-1,4-diyl)bis[1-(4-ethyl piperazine-1-yl) propan-2-ol], is capable of mediating facile conversion of methane into methanol upon activation of the tricopper cluster by dioxygen and/or $\mathrm{H}_{2} \mathrm{O}_{2}$ at room temperature. This is the first molecular catalyst that can catalyze selective oxidation of methane to methanol without over-oxidation under ambient conditions.

Michalkiewicz et al. ${ }^{98}$ investigated the catalytic properties of halogens in oleum. The reaction was performed with $\mathrm{I}_{2}, \mathrm{KI}, \mathrm{KBr}, \mathrm{KCl}, \mathrm{NaCl}$ and $\mathrm{HCl}$ used as catalysts and at $160^{\circ} \mathrm{C}, 4.27 \mathrm{MPa}$ methane pressure. It was found that Iodine $\left(\mathrm{I}_{2}\right)$ is the most effective catalyst.

Further studies revealed that $\mathrm{KBr}$ is a highly selective low temperature catalyst too, for homogeneous methane to methyl ester and then methanol conversion ${ }^{99}$. Sulfur trioxide as an oxidant and sulfuric acid as an esterification agent were used. The increase of temperature, sulfur trioxide concentration or methane pressure resulted in TOF grow. More investigations about mechanism and kinetics of the reaction are needed - further research is in progress.

\section{Methane Monooxygenase (MMO)}

The first reaction in this metabolic pathway is the conversion of methane to methanol catalyzed by the enzyme methane monooxygenase (MMO) as described in the report of Couderc and Baratti ${ }^{100}$.

Because of this perceived limitation in heterogeneous catalysts, the Weakely`s group undertook a program to take advantage of the selectivity already known to exist in a bacterial enzyme system. A group of aerobic soil/water bacteria called methanotrophs can efficiently and selectively utilize methane as the sole source of energy and carbon for cellular growth ${ }^{\mathbf{1 0 1}}$. The synthesis of the chelating ligand $\mathrm{HMeL}$ was obtained by a five step procedure in 35\% overall yield. Binuclear copper complexes of HMeL were prepared by dissolving 100 or $200 \mathrm{~mole} \%$ of cupric perchlorate with $100 \mathrm{~mole} \%$ $\mathrm{HMeL}$ and sodium acetate in methanol. The binuclear copper complex tested was capable of activating hydrogen peroxide and the presumed oxo-copper intermediate was able to oxidize alkanes.

Microorganisms can produce MMO in two distinct forms: a membrane-bound particulate form or a discrete soluble form. The soluble form contains an oxygenase subunit, whose active site includes a binuclear iron center ${ }^{102-107}$

In addition to inorganic catalysts that react with methane, it is well - known that a select group of aerobic soil/water bacteria called methanotrophs can efficiently and selectively utilize methane as the sole source of their energy and carbon for cellular growth ${ }^{108}$.

The ability of MMO to selectively oxidize methane to methanol under ambient conditions is quite impressive. Understanding how the enzyme performs will demystify this marvelous natural phenomenon. Methane is generated from carbon dioxide by methanogenic bacteria under anaerobic conditions such as lakes, oceans, and wetlands. Since both methane and dioxygen are essential for methanotrophs, these bacteria thrive in the borderline region of the aerobic and anaerobic environments ${ }^{109}$.

Michalkiewicz et al. ${ }^{110}$ applied the one-step method at very low temperatures $\left(35^{\circ} \mathrm{C}\right)$ by the methane oxidation to methanol via bacteria. The role of copper was investigated in the one-step methane oxidation to methanol by utilizing whole cells of Methylosinus trichosporium OB3b bacteria. From the obtained results it was found that copper concentration in the medium influences the rate of bacterial biomass growth or methanol production during the process of methane oxidation to methanol. The presented results indicate that the process of methane oxidation to methanol by Methylosinus trichosporium OB3b bacteria is most efficient when the mineral medium contains $1.0 \times 10^{-6} \mathrm{moldm}^{-3}$ of copper. Under these conditions, a satisfactory growth of biomass was also achieved.

Hadt and co-workers presented $\mathrm{Cu}-\mathrm{ZSM}-5$ as a biomimetic inorganic model for methane oxidation ${ }^{\mathbf{1 1 1}}$.

Sunney, Lu et al. developed a series of tricopper complexes that are capable of supporting facile catalytic oxidation of hydrocarbons. They investigated two tricopper complexes that are capable of facile conversion of methane to methanol: a tricopper-peptide complex derived from $\mathrm{MMO}$ and a biomimetic model tricopper complex. The biomimetic tricopper complex oxidizes methane efficiently at room temperature and can be formulated either as a homogeneous or heterogeneous catalyst ${ }^{112}$.

Analysis of the available results on biomimetic and bio - inspired methane oxygenation demonstrated that assimilating of the experience of nature on oxidation of methane and other alkane significantly enriches the arsenal of chemistry and can radically change the character of the entire chemical production, as well as enables the solution of many material, energetic and environmental problems ${ }^{113}$.

\section{CONCLUSIONS}

The conversion of methane to value-added liquid chemicals is a promising answer to the imminent demand for fuels and chemical synthesis materials in the advent of a dwindling petroleum supply. Current technology requires high energy input for synthesis gas production and is characterized by low overall selectivity, which calls for alternative reaction routes. The limitation to achieve high selectivity is the high $\mathrm{C}-\mathrm{H}$ bond strength 
of methane. High - temperature reaction systems favor gas - phase radical reactions and total oxidation. The use of homogeneous catalysts that activate and functionalize the $\mathrm{CH}$ bonds of unactivated hydrocarbons is very important. This results from the strong potential for these catalysts to carry out oxidative hydrocarbon conversion with high atom and energy efficiency and under mild conditions.

\section{LITERATURE CITED}

1. Energy Information Administration, Natural Gas Reserves (2013), http://www.eia.gov/naturalgas/

2. Michalkiewicz, B., Sreńscek-Nazzal, J. \& Ziebro, J. (2009). Optimization of synthesis gas formation in methane reforming with carbon dioxide. Catal. Lett. 129, 142-148. DOI: 10.1007/ s10562-008-9797-6.

3. Rynkowski, J.M., Paryjczak, T. \& Lenik, M. (1993). On the nature of oxidic nickel phase in $\mathrm{NiO} / \gamma-\mathrm{Al} 2 \mathrm{O} 3$ catalysts. Appl Catal A. 106, 73. DOI: 10.1016/0926-860X(93)80156-K.

4. Ziebro, J., Łukasiewicz, I., Grzmil, B., Borowiak-Palen, E. \& Michalkiewicz, B. (2009). Synthesis of nickel nanocapsules and carbon nanotubes via methane CVD. J. Alloys Compd. 485, 695-700. DOI: 10.1016/j.jallcom.2009.06.039.

5. Ziebro, J., Lukasiewicz, I., Borowiak-Palen, E. \& Michalkiewicz, B. (2010). Low temperature growth of carbon nanotubes from methane catalytic decomposition over nickel supported on a zeolite, Nanotechnology 21, 145308. DOI: 10.1088/0957$4484 / 21 / 14 / 145308$.

6. Ziebro, J., Skorupińska, B., Kądziołka, G. \& Michalkiewicz, B. (2013). Synthesizing multi-walled carbon nanotubes over supported-nickel catalyst. Fuller. Nanotub. Car. N. 21, 333-345. DOI: 10.1080/1536383X.2011.613543.

7. Michalkiewicz, B. \& Majewska, J. (2013). Low temperature one-step synthesis of cobalt nanowires encapsulated in carbon. Appl. Phys. A 111, 1013-1016. DOI: 10.1007/s00339-013-7698-z.

8. Ziebro, J., Łukasiewicz, I., Borowiak-Palen, E. \& Michalkiewicz, B. (2010). Low temperature growth of carbon nanotubes from methane catalytic decomposition over nickel supported on a zeolite. Nanotechnology 21, 145308. DOI: 10.1088/09574484/21/14/145308.

9. Sen, A. \& Lin, M. (2003). Catalytic partial oxidation of methane to methanol and formaldehyde, Am. Chem. Soc., 48, 2, 827. DOI: $10.1007 / \mathrm{s} 11244-005-2888-3$.

10. Dreisbach, F., Losch, H.W. \& Harting, P. (2002). Highest pressure adsorption equilibrium data: measurement with magnetic suspension balance and analysis with a new adsorbent/adsorbate-volume. Adsorption 8, 95. DOI: 10.1023/A:1020431616093.

11. Srenscek-Nazzal, J., Kaminska, W., Michalkiewicz, B. \& Koren, Z.C. (2013). Production, characterization and methane storage potential of $\mathrm{KOH}$-activated carbon from sugarcane molasses, Industrial Crops And Products 47, 153-159. DOI: 10.1016/j.indcrop.2013.03.004.

12. Azevedo, D.C.S., Cassia, J., Araujo, S., Bastos-Neto, M., Eurico, A., Torres, B. \& Jaguaribe E.F. (2007). Microporous activated carbon prepared from coconut shells using chemical activation with zinc chloride. Microporous Mesoporous Mater. Cavalcante C.L. 100, 361-364. DOI: 10.1016/j.micromeso.2006.11.024.

13. Sreńscek-Nazzal, J. \& Michalkiewicz, B. (2011). The simplex optimization for high porous carbons preparation, Pol. J. Chem. Tech. 13(4), 63-70. DOI: 10.2478/v10026-011-0051-4.

14. Lin, M. \& Sen, A. (1992). A highly catalytic system for the direct oxidation of lower alkanes by dioxygen in aqueous medium. A formal heterogeneous analog of alkane monooxygenases, J. Am. Chem. Soc. 114, 7307. DOI: 10.1021/ja00044a059.

15. Hammond, C., Forde, M.M, Rahim, M.H.A., Thetford, A., He, Q., Jenkins, R.L., Dimitratos, N. \& Lopez-Sanchez, J.A. (2012). Direct catalytic conversion of methane to methanol in an aqueous medium by using copper-promoted Fe-ZSM-5, Chemistry - A European Journal 18, 49, 15735-15745. DOI: 10.1002/anie.201108706.

16. Gang, X., Birch, H., Zhu, Y., Hjuler, H.A., Bjerrum N. J. (2000). Direct Oxidation of Methane to Methanol by Mercuric Sulfate Catalyst, Journal of Catalysis, 196, 2, 287-292. DOI: 10.1006/jcat.2000.3051.

17. Yamada, Y., Ueda, A., Shioyama, H. \& Kobayashi, T. (2003). High - throughput experiments on methane partial oxidations using molecular oxygen over silica doped with various elements, Appl. Catal. A. 254, 45. DOI: 10.1016/ S0926-860X(03)00262-X.

18. Otsuka, K. \& Hatano, M. (1987). The catalysts for the synthesis of formaldehyde by partial oxidation of methane, $J$. Catal. 108, 252. DOI: 10.1016/0021-9517(87)90172-2.

19. Parmaliana, A., Frusteri, F., Mezzapica, A., Scurrel, M. S. \& Giordano, N. (1993). Novel high activity catalyst for partial oxidation of methane to formaldehyde, J. Chem. Soc. Chem. Commun. 751. DOI: 10.1039/C39930000751.

20. Weng, T. \& Wolf, E.E. (1993). Partial oxidation of methane on mo/sn/p silica supported catalysts, Appl. Catal., 96, 383 DOI: 10.1016/0926-860X(90)80024-9.

21. Otsuka, K. \& Wang, Y. (2001). Direct conversion of methane into oxygenates, Appl. Catal., 222, 145. DOI: 10.1016/ S0926-860X(01)00837-7.

22. Spencer, N.D. (1988). Partial oxidation of methane to formaldehyde by means of molecular oxygen, J. Catal., 109, 143. DOI: 10.1016/0021-9517(88)90197-2.

23. Otsuka, K., Komatsu, T., Jinno, K., Uragami, Y. \& Morikawa, A. (1988). Proceedings of the $9^{\text {th }}$ International Congress on Catalysis, The Chemical Institute of Canada, Ottawa, 915.

24. Kastsnas, G.N., Tsigdios, G.A. \& Schwank, J. (1988). Selective oxidation of methane over vycor glass, quartz glass and various silica, magnesia and alumina surfaces, Appl. Catal. A., 44, 33-51. DOI: 10.1016/S0166-9834(00)80043-3.

25. Alptakin, G.O., Herring, A.M., Williamson, D.L., Ohno, T.R. \& McCormick, R.L. (1999). Methane Partial Oxidation by Unsupported and Silica Supported Iron Phosphate Catalysts: Influence of Reaction Conditions and Co-Feeding of Water on Activity and Selectivity, J. Catal., 181, 104-112. DOI: 10.1006/ jcat.1998.2297.

26. Sinev. M.Y., Setiadi, S. \& Otsuka, K. (1993). Selectivity Control by Oxygen Pressure in Methane Oxidation over Phosphate Catalysts, Mendeleev Commun., 10. DOI: 10.1016/ S0167-2991(08)63427-8.

27. Hargreaves, J.S.J., Hutchings, G.J. \& Joyner, R.W. (1990). Control of product selectivity in the partial oxidation of Methane, Nature, 348, 428. DOI: 10.1038/348428a0.

28. Michalkiewicz, B., Srenscek-Nazzal, J., Tabero, P., Grzmil, B. \& Narkiewicz, U. (2008). Chemical Papers, 62, 1, 106-113. DOI: $10.2478 / \mathrm{s} 11696-007-0086-4$.

29. Kałucki, K. \& Michalkiewicz, B. (2001). The effect of boron and magnesium additives on catalytic perform of Mo-0/ Si02 in the partial oxidation of methane, Pol. J. Chem. Tech., 3, 16-19.

30. Parmaliana, A., Frusteri, F., Arena, F., Mezzapica, A. \& Sokolovskii, V. (1998). Synthesis of methyl formate via two-step methane partial oxidation, Catal. Today, 46, 117-125. DOI: 10.1016/S0920-5861(98)00333-2.

31. Durante, V. \& Walker, D. (1990). EP 0393895.

32. Labinger, J.A. (1995). Methane activation in homogeneous systems, Fuel Process. Technol., 42, 325-338. DOI: 10.1016/0378-3820(94)00107-5.

33. Kaleńczuk, R.J. \& Ciarka, A. (2005). Materialy XXXVII Ogolnopolskiego Kolokwium Katalitycznego, 88.

34. Kudo, H. \& Ono, T. (1997). Partial oxidation of $\mathrm{CH}_{4}$ over ZSM-5 catalysts, Appl. Sci., 121/122, 413-416. DOI: 10.1016/ S0169-4332(97)00348-6.

35. Michalkiewicz, B. (2004). Partial oxidation of methane to formaldehyde and methanol using molecular oxygen over 
Fe-ZSM-5, Appl. Catal. A, 277, 147-153 DOI: 10.1016/j.apcata.2004.09.005.

36. Michalkiewicz, B. (2005) Kinetics of Partial Methane Oxidation Process over the Fe-ZMS-5 Catalysts, Chem. Pap., 59, 403-408 DOI: 10.1016/j.apcata.2004.09.005.

37. Hunter, N.R., Gesser, H.D., Morton, L.A. \& Fung, D.P.C., Prepr. 35 th Can. Chem. Eng. Conf., Calgary 6-9 Oct 1985.

38. Rytz, D.W. \& Baiker, A. (1991). Partial oxidation of methane to methanol in a flow reactor an elevated pressure, Ind. Eng. Chem. Res., 30, 2287-2292. DOI: 10.1021/ie00058a007.

39. Shilov, A.E. \& Shul'pin, G.B. (1997). Activation of C-H Bonds by Metal Complexes, Chem. Rev., 97, 2879-2932. DOI:10.1021/cr9411886.

40. Fu, G. \& Xu, X. Mechanistic Insights into Selective Oxidation of Light Alkanes by Transition Metal Compounds/ Complexes. In Computational Organometallic Chemistry;Wiest, O., Wu, Y., Eds.;Springer-Verlag: Berlin Heidelberg, Germany, 2012.

41. Gol` dshleger, N.F., Es`kova, V.V., Shilov, A.E. \& Steinman, A.A. (1972). Zh.Fiz. Khim., 46, 1353.

42. Lin, M., Hogan, T. \& Sen, A. (1997). A Highly Catalytic Bimetallic System for the Low-Temperature Selective Oxidation of Methane and Lower Alkane with Dioxygen as the Oxidant, J. Am. Chem. Soc., 119, 6048-6053. DOI: 10.1021/ja964371k. 43. Lin, M. \& Sen, A. (1996) US 5, 510, 525.

44. Lin, M., Hogan, T. \& Sen, A. (1996). Catalytic Carbon-Carbon and Carbon-Hydrogen Bond Cleavage in Lower Alkanes. Low-Temperature Hydroxylations and Hydroxycarbonylations with Dioxygen as the Oxidant, J. Am. Chem. Soc., 118, 4574-4580. DOI: 10.1021/ja953670r.

45. Park, E.D., Choi, S.H. \& Lee, J.S. (2000). Characterization of $\mathrm{Pd} / \mathrm{C}$ and $\mathrm{Cu}$ catalysts for the oxidation of methane to a methanol derivative, J. Catal.,194, 1, 33-34. DOI: 10.1006/ jcat.2000.2907.

46. Park, E.D., Hwang, Y.S. \& Lee, J.S. (2001). Direct conversion of methane into oxygenates by $\mathrm{H}_{2} \mathrm{O}_{2}$ generated in situ from dihydrogen and dioxygen, Catalysis Com.,187-190, DOI: 10.1016/S1566-7367(01)00030-9.

47. Ellis, P.E. \& Lyons, J.E. (1990), EP 0471561.

48. Ellis, P.E. \& Lyons, J.E. (1992), EP 0532327.

49. Nizova, G.V., Süss-Fink, G. \& Shul pin, G.B. (1997). Catalytic oxidation of methane to methyl hydroperoxide and other oxygenates under mild conditions, Chem. Commun., 397-398. DOI: 10.1039/A607765J.

50. Nizova, G.V., Süss-Fink, G.,Stanislas, S. \& Shul `pin, G.B. (1998). xidations by the reagent $\mathrm{O}_{2}-\mathrm{H}_{2} \mathrm{O}_{2}$ - vanadate anion pyrazine-2-carboxylic acid'.: Part 10. Oxygenation of methane in acetonitrile and water, J. Mol. Catal. A. Chem., 130, 1-2, 163-170 DOI: 10.1016/S1381-1169(97)00210-0.

51. Lee, B-J., Kitsukawa, S., Nakagawa, H., Asakura, S. \& Fukuda, K. (1998). The Partial Oxidation of Methane to Methanol with Nitrite and Nitrate Melts, Z. Naturforsch., 679.

52. Peng, J. \& Deng, Y. (2000). Direct catalytic conversion of methane in molten salt medium system under mild conditions, Appl. Catal. A, 201, 2, 155-157. DOI: 10.1016/S0926$-860 \mathrm{X}(00) 00561-5$.

53. Sherman, J.H. (1999). US 5954925.

54. Stauffer, J.E. (1993). US 5185479.

55. Seki, Y., Mizuno, N. \& Misono, M. (1997). High-yield liquid-phase oxygenation of methane with hydrogen peroxide catalyzed by 12-molybdovanadophosphoric acid catalyst precursor, Appl. Catal. A. ,158, 1-2, 47-51. DOI: 10.1016/ S0926-860X(97)00177-4.

56. Seki, Y., Min, J. S., Mizuno, N. \& Misono, M. (2000). Reaktion mechanism of oxidation of methane with hydrogenperoxide catalysed by 1,1 - molybdo - 1 vanadophosphoric acid catalyst precursor, J. Phys. Chem. B.,104, 5940-5944. DOI: $10.1021 /$ jp000406y.

57. Periana, R.A., Taube, H. \& Evitt, E.R. (1993). US 5, $233,113$.
58. Periana, R.A., Taube, D.J., Gamble, S., Taube, H., Satoh, T. \& Fujii, H. (1998). Platinum Catalysts for the High-Yield Oxidation of Methane to a Methanol Derivative, Science, 280 560-564. DOI: 10.1126/science.280.5363.560.

59. Michalkiewicz, B., Kałucki, K. \& Sośnicki, J.G. (2003). Catalytic system containing metallic palladium in the process methane partial oxidation, J. Catal., 215, 14-19. DOI: 10.1016/ S0021-9517(02)00088-X.

60. Mukhopadhyay, S. \& Bell, A.T. (2003). Direct catalytic sulfonation of methane with $\mathrm{SO}_{2}$ to methanesulfonic acid (MSA) in the presence of molecular $\mathrm{O}_{2}$, Chem. Commun, 1590-1591. DOI: 10.1039/B303561A.

61. Mukhopadhyay, S., Bell, A.T. \& Zerella, M. (2005). A High-Yield, Liquid-Phase Approach for the Partial Oxidation of Methane to Methanol using $\mathrm{SO}_{3}$ as the Oxidant, Adv.Synth. Catal., 347, 1203-1206. DOI: 10.1002/adsc.200404394.

62. Cheng, J., Li, Z., Haught, M. \& Tang, Y. (2006) Direct methane conversion to methanol by ionic liquid-dissolved platinum catalysts, Chem. Commun., 4617-4619. DOI: 10.1039/ b610328f.

63. Periana, R.A., Taube, D.J., Evitt, E.R., Löffler, D.G., Wentrcek, P.R., Voss, G. \& Masuda, T. (1993). A Mercury-Catalyzed, High-Yield System for the Oxidation of Methane to Methanol, Science, 259 340-343. DOI: 10.1126/science.259.5093.340.

64. Gang, X., Birch, H., Zhu, Y., Hjuler, H.A. \& Bjerrum, N.J. (2000). Direct Oxidation of Methane to Methanol by Mercuric Sulfate Catalyst, J. Catal. 196, 2, 287-292. DOI: 10.1006/jcat.2000.3051.

65. Sen, A., Benvenuto, M.A., Lin, M., Hutson, A.C. \& Basickes, N. (1994). Activation of Methane and Ethane and Their Selective Oxidation to the Alcohols in Protic Media, $J$. Am. Chem. Soc. 116, 3, 998-1003 DOI: 10.1021/ja00082a022.

66. Basickes, N., Hogan, T.E. \& Sen, A. (1996). Radical-Initiated Functionalization of Methane and Ethane in Fuming Sulfuric Acid, J. Am. Chem. Soc., 118, 51, 13111-13112 DOI: $10.1021 /$ ja9632365.

67. Mukhopadhyay, S. \& Bell, A.T. (2004). Catalyzed sulfonation of methane to methanesulfonic acid, Journal of Molecular Catalysis, 211,1 - 2, 59-65. DOI: 10.1016/j.molcata.2003.10.015.

68. Fu, G., Xu, X. \& Wan, H. (2006). Mechanism of methane oxidation by transition metal oxides: A cluster model study, $\mathrm{Ca}$ tal. Today, 117, 1-3, 133-137. DOI: 10.1016/j.cattod.2006.05.048.

69. Carley A.F., Davies P.R. \& Roberts M.W. (2005). Activation of oxygen at metal surfaces, Phil. Trans. R. Soc. A, 363, 829-846. DOI:10.1098/rsta.2004.1544.

70. Catlow, C.R.A., French, S.A., Sokol, A.A. \& Thomas, J.M. (2005). Computational approaches to the determination of active site structures and reaction mechanisms in heterogeneous catalysts, Phil. Trans. R. Soc. A, 363, 913-936. DOI:10.1098/ rsta.2004.1529.

71. Sun, M., Zhang, J., Putaj, P., Caps, V., Lefebvre, F., Pelletier, J. \& Basset, J.M. (2013). Catalytic Oxidation of Light Alkanes $(\mathrm{C} 1-\mathrm{C} 4)$ by Heteropoly Compounds, Chem. Rev. 2014, 114, 981-1019. DOI.org/10.1021/cr300302b.

72. Kao, L.C., Hutson, A.C. \& Sen, A. (1991). Low-Temperature, Palladium(I1)-Catalyzed, Solution-Phase Oxidation of Methane to a Methanol Derivative, J. Am. Chem. Soc. 113, 2, 700-701 DOI: 10.1021/ja00002a063.

73. Taylor, Ch.E., Anderson, R.R. \& Noceti, R.P. (1997). Activation of methane with organopalladium complexes, Catalysis Today, 35, 4, 407-413. DOI: 10.1016/S0920-5861(96)00213-1.

74. Michalkiewicz, B. (2003). Methane Conversion to Methanol in Condensed Phase, Kinet. Catal., 44, 6, 801-805. DOI: 10.1023/B:KICA.0000009057.79026.0b.

75. Michalkiewicz, B. \& Kałucki, K. (2003). The Role of Pressure in the Partial Methane Oxidation Process in the Pd-Oleum Environment, Chem. Pap., 57, 6, 393-396.

76. Michalkiewicz, B. (2006). Methane esterification in oleum, Chem. Pap., 602, 5, 371-374. DOI: 10.2478/s11696-006-0067-z. 
77. Michalkiewicz, B., Ziebro, J. \& Tomaszewska, M. (2006). Preliminary investigation of low pressure membrane distillation of methyl bisulphate from its solutions in fuming sulphuric acid combined with hydrolysis to methanol, J. Membrane Sci., 286, 1-2, 223-227. DOI: 10.1016/j.memsci.2006.09.039.

78. Periana, R.A., Mironov, O., Taube, D.J., Bhalla, G. \& Jones, C.J. (2003). Catalytic, Oxidative Condensation of $\mathrm{CH}_{4}$ to $\mathrm{CH}_{3} \mathrm{COOH}$ in One Step via $\mathrm{CH}$ Activation, Science, 301, 5634, 814-818. DOI: 10.1126/science.1086466.

79. Michalkiewicz, B. (2006). The kinetics of homogeneous catalytic methane oxidation, Appl. Catal. A, 307, 2, 270-274. DOI: 10.1016/j.apcata.2006.04.006.

80. Michalkiewicz, B. \& Kosowski, P. (2007). The selective catalytic oxidation of methane to methyl bisulfate at ambient pressure, Catal. Commun.,8, 12, 1939-1942. DOI: 10.1016/j. catcom.2007.03.014.

81. Gang, X., Zhu, Y., Birch, H., Aage, H., Hjuler, A. \& Bjerrum, N. (2004). Iodine as catalyst for the direct oxidation of methane to methyl sulfates in oleum, Appl. Catal. A., 261, 1, 91-98. DOI: 10.1016/j.apcata.2003.10.039.

82. Periana, R.A., Mironov, O., Taube, D.J., Bhalla, G., Gamble, S. (2002). High Yield Conversion of Methane to Methyl bisulfate Catalyzed by Iodine Cations, Chem. Commun., 2376-2377. DOI: 10.1039/B205366G.

83. Zerella, M., Bell, A.T. (2006). Pt-catalyzed oxidative carbonylation of methane to acetic acid in sulfuric acid, Journal of Molecular Catalysis, 259, 1-2, 296-301. DOI: 10.1016/j. molcata.2006.06.059.

84. Michalkiewicz, B., Jarosińska, M. \& Łukasiewicz, I. (2009). Kinetic study on catalytic methane esterification in oleum catalyzed by iodine, Chem. Engineer. J., 154, 1-3, 156-161. DOI: 10.1016/j.cej.2009.03.046.

85. Michalkiewicz, B. (2011) Methane oxidation to methylbisulfate in oleum at ambient pressure in the presence of iodine as a catalyst, Appl. Catal. A., 394, 1-2, 266-268. DOI: 10.1016/j.apcata.2011.01.014.

86. Vargaftik, M.N., Stolarov, I.P. \& Moiseev, I.L. (1990). Highly selective partial oxidation of methane to methyl trifluoroacetate, J. Chem. Soc.,Chem. Commun., 1049-1050 DOI: $10.1039 /$ C39900001049.

87. Yamanaka, I., Soma, M. \& Otsuka, K. (1995). Oxidation of methane to methanol with oxygen catalyzed by europium trichloride at room-temperature, J.Chem. Soc., Chem. Commun., 2235-2236. DOI: 10.1039/C39950002235.

88. Yamanaka, I., Soma, M. \& Otsuka, K. (1996). Enhancing effect of titanium (II) for the oxidation of methane with $\mathrm{O}$ 2 by an EuCL3 - Zn -CF3CO2H - catalytic system at $40^{\circ}$, Chem. Lett., 565. DOI: 10.1246/cl.1996.565.

89. Mukhopadhyay, S. \& Bell, A. (2004). Direct sulfonation of methane to methanesulfonic acid by sulfur trioxide catalyzed by cerium(IV) sulfate in the presence of molecular oxygen, Advanced Synthesis \& Catalysis, 348, 913-916. DOI: 10.1002/ adsc. 200404060.

90. Mukhopadhyay, S. \& Bell, A. (2003). Direct liquid-phase sulfonation of methane to methanesulfonic acid by $\mathrm{SO}_{3}$ in the presence of a metal peroxide, Angew. Chem. Internat. Edition, 42, 9, 1019-1021. DOI: 10.1002/anie.200390260.

91. Mukhopadhyay, S. \& Bell, A. (2003) Direct sulfonation of methane at low pressure to methanesulfonic acid in the presence of potassium peroxydiphosphate as the initiator, Organic Process Research \& Development, 7, 2, 161-163, DOI: 10.1021/ op020079n.

92. Jones, C.J., Taube, D., Periana, R.A., Nielsen, R.J., Oxgaard, J. \& Goddard, W.A. (2004). Selective oxidation of methane to methanol catalyzed, with $\mathrm{C}-\mathrm{H}$ activation, by homogeneous, cationic gold, Angewandte Chemie, International Edition, 116, 35, 4626-4629. DOI: 10.1002/ange.200461055.

93. Lobree, L.J. \& Bell, A.T. (2001). $\mathrm{K}_{2} \mathrm{~S}_{2} \mathrm{O}_{8}$-initiated sulfonation of methane to methanesulfonic acid, Ind. Eng. Chem. Res., 40, 3, 736-742. DOI: 10.1021/ie000725b.
94. Periana, R.A., Hashiguchi, B.G., Konnick, M., Bischof, S.M., Gustafson, S.J. Devarajan, D., Gunsalus, N. \& Ess, D.H. (2014). Main group compounds selectively oxidize mixtures of methane, ethane, and propane to alcohol esters, Science, 343, 6176, 1232-1237. DOI: 10.1126/science.1249357.

95. Wang, K.X., Xu, H.F., Li, W.S., Au, C.T. \& Zhou, X.P. (2006). The synthesis of acetic acid from methane via oxidative bromination, carbonylation, and hydrolysis, Applied Catalysis A, 304, 10, 168-177. DOI: 10.1016/j.apcata.2006.02.035.

96. Fengbo, L., Guoqing, Y., Fang, Y. \& Fengwen, Y. (2008). Bromine-mediated conversion of methane to $\mathrm{C} 1$ oxygenates over Zn-MCM-41 supported mercuric oxide, Appl. Catal. A: General 335, 1, 82-87. DOI: 10.1016/j.apcata.2007.11.014.

97. Chan, S.I., Nagababu, P., Yu, S.S.F., Maji, S. \& Ramu, R. (2014). Developing an efficient catalyst for controlled oxidation of small alkanes under ambient conditions, Catal. Sci. Technol., 4, 930-935. DOI: 10.1039/C3CY00884C.

98. Jarosińska, M., Lubkowski, K., Sośnicki, J.G., Michalkiewicz, B. (2008). Application of halogens as catalysts of $\mathrm{CH}_{4}$ esterification, Catal. Lett., 126, 3-4, 407-412. DOI: 0.1007/ s10562-008-9645-8.

99. Michalkiewicz, B. \& Balcer, S. (2012). Bromine catalyst for the methane to methyl bisulfate reaction, Pol. J. Chem. Technol., 14, 4, 19-21. DOI: 10.2478/v10026-012-0096-z.

100. Couderc, R. \& Baratti, J. (1980). Oxidations of hydrocarbons by methane by the yeast Pichia pastoris. Purification and properties of the alcohol oxidase, Adv. Appl. Microbiol., 44, 2279-2289.

101. Droege, M.W., Satcher, J.H., Reibold, R.A., Weakely', T.J.R., Chauffe, L. \& Watkins, B.E. (1992). Application of coordinating Complexes containing an asymmetric coordinating ligand, 1534.

102. Woodland, M.P. \& Dalton, H.J. (1984). Purification and characterization of component $\mathrm{A}$ of the methane monooxygenase from Methylococcus capsulatus (Bath), Biol. Chem., $259,53-59$.

103. Green, J. \& Dalton, H.J. (1985). Protein B of soluble methane monooxygenase from Methylococcus capsulatus (Bath). A novel regulatory protein of enzyme activity, Biol. Chem., 260, 29, 15795-15801.

104. Woodland, M.P., Patil, D.S., Cammack, R. \& Dalton, H. (1986). ESR Studies of protein A of the soluble methane monooxygenase from Methylococcus capsulatus (Bath), Biochim. Biophys. Acta, 873, 237-242.

105. Fox, B.G., Surerus, K.K., Munck, E. \& Lipscomb, J.D.J. (1988). Evidence for a mu-oxo-bridged binuclear iron cluster in the hydroxylase component of methane monooxygenase Mössbauer and EPR studies, J. Biol. Chem., 263, 10553-10556.

106. Prince, R.C., George, G.N., Savas, J.C., Cramer, S.P., Patel, R.N. (1988). Spectroscopic properties of the hydroxylase of methane monooxygenase, Biochim. Biophys. Acta, 952, 220-229.

107. DeWitt, J.G., Benhen, J.G., Rosenzweig, A.C., Hedman, B., Green, J., Pilkington, S., Papaefthymiou, G.C., Dalton, H., Hodgson, K.O. \& Lippard, S.J.J. (1992). Biomimetic catalysts application of coordinating complexes containing an asymmetric coordinating ligand, Am. Chem. Soc., 113, 9219-9235.

108. Fox, B.G., Froland, W.A., Dege, J.E. \& Lipscomb, J.D.J. (1989). Methane monooxygenase from Methylosinus trichosporium OB3b. Purification and properties of a threecomponent system with a high specific activity from a type II methanotrophs, Biol. Chem., 264, 10023-10033.

109. Merkx, M., Kopp, D.A., Sazinsky, M.H., Blazyk, J.L., Muller, J. \& Lippard, S.J. (2001). Dioxygen Activation and Methane Hydroxylation by Soluble Methane Monooxygenase: A Tale of Two Irons and Three Proteins A list of abbreviations can be found in Section 7, Angew.Chem., Int. Ed., 40, 2782-2807. DOI: 10.1002/1521-3773(20010803)40:153.3.CO;2-G.

110. Markowska, A. \& Michalkiewicz, B. (2009). Biosynthesis of methanol from methane by Methylosinus trichosporium 
OB3, Chemical Papers, 63, 2, 105-110. DOI: 10.2478/s11696008-0100-5.

111. Vanelderen, P., Hadt, R.G., Smeets, P.J., Solomon,, E.I., Schoonheydt R.A. \& Sels, B.F. (2011). Cu-ZSM-5: A biomimetic inorganic model for methane oxidation, J. Catal., 284, 2, 157-164. DOI: 10.1016/j.jcat.2011.10.009.

112. Chan, S.I., Lu, Y.J., Nagababu, P., Maji, S., Hung, M.Ch., Lee, M.M., Hsu, I.J., Minh, P.D., Lai, J.C.H., Kok, Y.N., Sridevi, R., Steve, S.F. Yu, Michael K. Chan. (2013). Efficient oxidation of methane to methanol by dioxygen mediated by tricopper clusters, Angew. Chem.Int. Ed., 52, 3731-3735. DOI: 10.1002/ anie.201209846.

113. Shilov, A.E. \& Shteinman, A.A. (2012). Methane hydroxylation: a biomimetic approach, Russ. Chem.Rev., 81, 4, 291. DOI: $10.1070 / \mathrm{RC} 2012 \mathrm{v} 081 \mathrm{n} 04 \mathrm{ABEH} 004271$. 